\title{
Manganese(II) $\beta$-Diketonate Complexes with Pyridin-4-one, 3-Hydroxypyridin-2-one and 1-Fluoropyridine Ligands: Molecular Structures and Hydrogen-bonded Networks
}

\author{
Anže Čavić and Franc Perdih* \\ Faculty of Chemistry and Chemical Technology, University of Ljubljana, Večna pot 113, P. O. \\ Box 537, SI-1000 Ljubljana, Slovenia \\ ${ }^{*}$ Corresponding author: E-mail: franc.perdih@fkkt.uni-lj.si
}

Received: 08-21-2020

\begin{abstract}
Manganese(II) bis(4,4,4-trifluoro-1-phenylbutane-1,3-dionate) complexes with pyridin-4-one (pyon), 3-hydroxypyridin-2-one (hpyon), 1-fluoropyridine (pyF) and methanol were prepared and the solid-state structures were determined by single-crystal X-ray analysis. The coordination of the metal center in all complexes was found to be octahedral. In compounds $\left[\mathrm{Mn}(\mathrm{tfpb})_{2}(\text { pyon })_{2}\right](\mathbf{1})$ and $\left[\mathrm{Mn}(\mathrm{tfpb})_{2}(\mathrm{hpyon})_{2}\right](2)$ extended hydrogen bonding is present facilitating the formation of a three-dimensional supramolecular structure in $\mathbf{1}$ and a layered structure in $\mathbf{2}$ through $\mathrm{N}-\mathrm{H} \cdots \mathrm{O}$ hydrogen bonding enhanced by $\mathrm{C}-\mathrm{H} \cdots \mathrm{O}$ interactions as well as $\mathrm{C}-\mathrm{F} \cdots \pi$ interactions. $\mathrm{In}\left[\mathrm{Mn}(\mathrm{tfpb})_{2}(\mathrm{pyF})_{2}\right](3)$ a layered structure is formed through $\mathrm{C}-\mathrm{H} \cdots \mathrm{O}$ and $\mathrm{C}-\mathrm{H} \cdots \mathrm{F}$ interactions as well as $\pi \cdots \pi$ and $\mathrm{C}-\mathrm{F} \cdots \pi$ interactions. $\mathrm{In}\left[\mathrm{Mn}(\mathrm{tfpb})_{2}(\mathrm{MeOH})_{2}\right](4)$ a layered structure is formed through a combination of $\mathrm{O}-\mathrm{H} \cdots \mathrm{O}$ and $\mathrm{C}-\mathrm{F} \cdots \pi$ interactions.
\end{abstract}

Keywords: $\beta$-Diketonates; manganese; pyridines; crystal structure; $\pi \cdots \pi$ interaction

\section{Introduction}

Inorganic-organic hybrids, metal-organic coordination polymers and especially metal-organic frameworks (MOFs) are currently an extremely important topic and an active area of research because of their intriguing architectures and topologies, ${ }^{1,2}$ as well as due to their potential applications in catalysis, chemical separation processes, wastewater treatment, gas storage, magnetism and as sensors. ${ }^{3}$ Control of the solid-state arrangement of molecules within a crystal is the central challenge of materials chemistry. In metal-organic frameworks and coordination polymers, covalent bonding using bridging organic ligands for creation of robust polymeric structures is of prime importance. Various kinds of these materials have been designed with special attention dedicated to the geometry of the metal ions as well as flexibility, bridging potential and coordination preferences of different organic linkers. ${ }^{1}$ On the other hand, in inorganic-organic hybrids non-covalent bonds adjust the dimensionality and enable new topologies to arise. Non-covalent forces, such as hydrogen bonding, $\mathrm{C}-\mathrm{H} \cdots \pi / \mathrm{F}$ interactions, $\pi \cdots \pi$ stacking, and halogen bonding are much weaker compared to the covalent bonds, however, their multitude makes them a powerful tool in the crystal engineering. Also, a great variety of non-covalent donors-acceptors and their numbers, their unique directionality and simple introduction into structures make them a particularly good choice for the construction of self-assemblies.

Here we report the influence of pyridin-4-one (4-pyridone; pyon), 3-hydroxypyridin-2-one (hpyon), and 1-fluoropyridine (pyF) ligands on the molecular and supramolecular structure in the cases of $\left[\mathrm{Mn}(\mathrm{tfpb})_{2}(\text { pyon })_{2}\right]$ (1), $\left[\mathrm{Mn}(\mathrm{tfpb})_{2}(\mathrm{hpyon})_{2}\right]$ (2), $\left[\mathrm{Mn}(\mathrm{tfpb})_{2}(\mathrm{pyF})_{2}\right]$ (3) complexes as well as the structure of $\left[\mathrm{Mn}(\mathrm{tfpb})_{2}(\mathrm{MeOH})_{2}\right](4)$, where tfpb is the 4,4,4-trifluoro-1-phenylbutane-1,3-dionate (or 4,4,4-trifluoro-3-oxo-1-phenylbutan-1-olate) ligand. The tfpb ligand was selected because it is not symmetric and possesses phenyl and trifluoromethyl groups enabling also the formation of $\mathrm{C}-\mathrm{H} \cdots \mathrm{F}, \mathrm{F} \cdots \mathrm{F}$ and $\mathrm{C}-\mathrm{F} \cdots \pi$ interactions besides the $\pi \cdots \pi$ and $\mathrm{C}-\mathrm{H} \cdots \pi$ interactions. ${ }^{4}$ Pyridin-4-on and 3-hydroxypyridin-2-one were selected since the tautomeric equilibrium between the lactam and lactim forms enables various coordination modes and also 
due to their different hydrogen bond formation abilities when coordinated in lactam/lactim form. On the other hand, 1-fluoropyridine was selected in order to be able to study the influence of an additional fluorine substituent on the formation of supramolecular aggregation in the absence of the competing strong hydrogen bond donors.

\section{Experimental}

\section{1. Materials and Characterization}

Reagents and chemicals were obtained as reagent grade from commercial sources and were used as purchased without any further purification. $\left[\mathrm{Mn}(\mathrm{tfpb})_{2}\left(\mathrm{H}_{2} \mathrm{O}\right)_{2}\right]$ was prepared according to the literature procedure. ${ }^{5}$ Infrared (IR) spectra $\left(4000-600 \mathrm{~cm}^{-1}\right)$ of the samples were recorded using a Perkin-Elmer Spectrum 100, equipped with a Specac Golden Gate Diamond ATR as a solid sample support. Elemental $(\mathrm{C}, \mathrm{H}, \mathrm{N})$ analyses were obtained using a Perkin-Elmer 2400 Series II CHNS/O Elemental Analyzer.

\section{2. Synthesis}

\section{Synthesis of $\left[\mathrm{Mn}(\mathrm{tfpb})_{2}(\text { pyon })_{2}\right](1)$ \\ $\left[\mathrm{Mn}(\mathrm{tfpb})_{2}\left(\mathrm{H}_{2} \mathrm{O}\right)_{2}\right] \quad(0.065 \mathrm{~g}, 0.125 \mathrm{mmol})$ was} dissolved in acetone $(8 \mathrm{~mL})$ and then pyon $(0.024 \mathrm{~g}$, $0.250 \mathrm{mmol}$ ) was added. The reaction mixture was stirred for $15 \mathrm{~min}$ at $\sim 50{ }^{\circ} \mathrm{C}$ and then allowed to stand at room temperature. Orange crystals suitable for X-ray analysis were obtained after slow evaporation of the solvent over a few days. Yield: 0.036 g, $43 \%$. Anal. Calcd. [Mn(tfpb $)_{2}(\text { pyon })_{2}$ ] $\left(\mathrm{C}_{30} \mathrm{H}_{22} \mathrm{~F}_{6} \mathrm{MnN}_{2} \mathrm{O}_{6}\right) \quad(\mathrm{MW}=675.44): \mathrm{C} 53.35, \mathrm{H}$ 3.28, $\mathrm{N} 4.15$; Found C 52.92, H 2.90, N 4.06. IR (ATR, $\mathrm{cm}^{-1}$ ): 3244w, 3080w, 2663w, 1606s, 1597m, 1573m, 1527m, 1501m, $1471 \mathrm{~s}, 1374 \mathrm{~m}, 1315 \mathrm{~m}, 1283 \mathrm{~s}, 1248 \mathrm{~m}, 1179 \mathrm{~s}, 1127 \mathrm{~s}, 1072 \mathrm{~m}$, $1025 \mathrm{~m}, 996 \mathrm{~m}, 939 \mathrm{~m}, 831 \mathrm{~m}, 763 \mathrm{~m}, 717 \mathrm{~m}, 697 \mathrm{~s}, 635 \mathrm{~m}$.

\section{Synthesis of $\left[\mathrm{Mn}(\mathrm{tfpb})_{2}(\text { hpyon })_{2}\right]$ (2)}

$\left[\mathrm{Mn}(\mathrm{tfpb})_{2}\left(\mathrm{H}_{2} \mathrm{O}\right)_{2}\right](0.065 \mathrm{~g}, 0.125 \mathrm{mmol})$ was dissolved in warm ethanol $(12 \mathrm{~mL})$ and then hpyon $(0.028 \mathrm{~g}$, $0.250 \mathrm{mmol}$ ) was added. The reaction mixture was stirred for $15 \mathrm{~min}$ at $\sim 60^{\circ} \mathrm{C}$ and then allowed to stand at room temperature. Orange crystals suitable for X-ray analysis were obtained after slow evaporation of the solvent over a few days. Yield: $0.058 \mathrm{~g}, 66 \%$. Anal. Calcd. [Mn(tfpb $)_{2}(\mathrm{~h}-$ pyon $\left.)_{2}\right]\left(\mathrm{C}_{30} \mathrm{H}_{22} \mathrm{~F}_{6} \mathrm{MnN}_{2} \mathrm{O}_{8}\right)(\mathrm{MW}=707.44)$ : $\mathrm{C} 50.91, \mathrm{H}$ 3.14, N 3.96; Found C 50.72, H 3.14, N 3.90. IR (ATR, $\mathrm{cm}^{-1}$ ): 3251w, 3120w, 2958w, 1605m, 1596m, 1570s, $1543 \mathrm{~m}, 1529 \mathrm{~m}, 1491 \mathrm{~m}, 1471 \mathrm{~m}, 1456 \mathrm{~m}, 1419 \mathrm{~m}, 1377 \mathrm{~m}$, $1284 \mathrm{~s}, 1251 \mathrm{~m}, 1187 \mathrm{~s}, 1134 \mathrm{~s}, 1058 \mathrm{~m}, 937 \mathrm{~m}, 885 \mathrm{~m}, 761 \mathrm{~s}$, $717 \mathrm{~m}, 699 \mathrm{~s}, 635 \mathrm{~m}$.

\section{Synthesis of $\left[\mathrm{Mn}(t \mathrm{tpb})_{2}(p y F)_{2}\right]$ (3)}

$\left[\mathrm{Mn}(\mathrm{tfpb})_{2}\left(\mathrm{H}_{2} \mathrm{O}\right)_{2}\right](0.065 \mathrm{~g}, 0.125 \mathrm{mmol})$ was dissolved in pyF $(2 \mathrm{~mL})$. The reaction mixture was stirred for
15 min at $\sim 60^{\circ} \mathrm{C}$ and then allowed to stand at room temperature. Orange crystals suitable for X-ray analysis were obtained after slow evaporation of the solvent over a few days. Yield: $0.045 \mathrm{~g}, 53 \%$. Anal. Calcd. [Mn(tfpb $)_{2}(\mathrm{pyF})_{2}$ ] $\left(\mathrm{C}_{30} \mathrm{H}_{20} \mathrm{~F}_{8} \mathrm{MnN}_{2} \mathrm{O}_{4}\right)(\mathrm{MW}=679.42): \mathrm{C} 53.02, \mathrm{H} 2.97, \mathrm{~N}$ 4.12; Found C 52.55, H 2.81, N 3.99. IR (ATR, $\left.\mathrm{cm}^{-1}\right)$ : $3381 \mathrm{br}, 1609 \mathrm{~s}, 1597 \mathrm{~m}, 1574 \mathrm{~s}, 1532 \mathrm{~m}, 1490 \mathrm{~m}, 1458 \mathrm{~m}$, $1318 \mathrm{~m}, 1281 \mathrm{~s}, 1248 \mathrm{~m}, 1182 \mathrm{~s}, 1129 \mathrm{~s}, 1096 \mathrm{~m}, 1075 \mathrm{~m}$, 1025w, 941w, 798w, 768m, 718m, 699s, 635s.

\section{Synthesis of $\left[\mathrm{Mn}(\mathrm{tfpb})_{2}(\mathrm{MeOH})_{2}\right](4)$}

$\left[\mathrm{Mn}(\mathrm{tfpb})_{2}\left(\mathrm{H}_{2} \mathrm{O}\right)_{2}\right](0.065 \mathrm{~g}, 0.125 \mathrm{mmol})$ was dissolved in warm methanol $(12 \mathrm{~mL})$ and then pyon $(0.024 \mathrm{~g}$, $0.250 \mathrm{mmol}$ ) was added. The reaction mixture was stirred for $15 \mathrm{~min}$ at $\sim 60{ }^{\circ} \mathrm{C}$ and then allowed to stand at room temperature. Orange crystals suitable for X-ray analysis were obtained after slow evaporation of the solvent over a few days. Yield: $0.040 \mathrm{~g}, 58 \%$. Anal. Calcd. [Mn(tfpb $)_{2}$ $\left.(\mathrm{MeOH})_{2}\right]\left(\mathrm{C}_{22} \mathrm{H}_{20} \mathrm{~F}_{6} \mathrm{MnO}_{6}\right)(\mathrm{MW}=549.32): \mathrm{C} 48.10, \mathrm{H}$ 3.67; Found $\mathrm{C}$ 47.94, $\mathrm{H}$ 3.38. IR (ATR, $\mathrm{cm}^{-1}$ ): 2538br, $2421 \mathrm{br}, 1928 \mathrm{w}, 1876 \mathrm{w}, 1644 \mathrm{~m}, 1602 \mathrm{~m}, 1574 \mathrm{~m}, 1350 \mathrm{~s}$, $1321 \mathrm{~m}, 1259 \mathrm{~m}, 1228 \mathrm{~m}, 1191 \mathrm{~s}, 1134 \mathrm{~m}, 995 \mathrm{~s}, 934 \mathrm{~s}, 821 \mathrm{~s}$, $811 \mathrm{~s}, 748 \mathrm{w}, 635 \mathrm{~s}$.

\section{3. X-ray Crystallography}

Single-crystal X-ray diffraction data were collected at room temperature $(\mathbf{1}, \mathbf{2}, \mathbf{4})$ or $150 \mathrm{~K}(\mathbf{3})$ on a Nonius Kappa CCD diffractometer or an Agilent Technologies SuperNova Dual diffractometer with an Atlas detector using monochromated Mo- $K_{\alpha}$ radiation $(\lambda=0.71073 \AA)$. The data were processed using $\mathrm{DENZO}^{6}$ or CrysAlis Pro. ${ }^{7}$ The structures were solved by direct methods implemented in SHELXS ${ }^{8}$ and SIR- $97^{9}$ and refined by a full-matrix leastsquares procedure based on $F^{2}$ with SHELXL. ${ }^{8}$ All non-hydrogen atoms were refined anisotropically. All $\mathrm{H}$ atoms were initially located in a difference Fourier maps. The hydrogen atoms on carbon atoms were treated as riding atoms in geometrically idealized positions. Hydrogen atoms attached to nitrogen and oxygen atoms were refined fixing the bond lengths and isotropic temperature factors as $U_{\text {iso }}(\mathrm{H})=k U_{\text {eq }}(\mathrm{N}, \mathrm{O})$, where $k=1.5$ for $\mathrm{OH}$ groups, and 1.2 for $\mathrm{NH}$ groups. In $\mathbf{1}$ and $\mathbf{4}$ the $\mathrm{CF}_{3}$ groups are disordered over two positions in 0.76(2):0.24(2) and 0.71(3):0.29(3) (in 1) and 0.66(3):0.34(3) (in 4) ratio. In 1 a possible pseudo-translation was detected, however, no additional space group could be found using the Platon program. The crystallographic data are listed in Table 1.

\section{Results and Discussion}

Initial attempts to prepare $\mathbf{1}$ using methanol as a solvent gave $\mathbf{4}$ as the sole product. Thus, in the subsequent attempts of its synthesis other solvents were used instead. Compounds 1 and 2 were obtained by the reaction of

Čavić and Perdih: $\quad$ Manganese(II) $\beta$-Diketonate Complexes ... 
Table 1. Crystallographic and refinement data for 1-4.

\begin{tabular}{|c|c|c|c|c|}
\hline Parameter & $\begin{array}{c}{\left[\mathrm{Mn}(\mathrm{tfpb})_{2}(\text { pyon })_{2}\right]} \\
(1)\end{array}$ & {$\left[\begin{array}{c}\left.\mathrm{Mn}(\mathrm{tfpb})_{2}(\text { hpyon })_{2}\right] \\
(2)\end{array}\right.$} & $\begin{array}{c}{\left[\mathrm{Mn}(\mathrm{tfpb})_{2}(\mathrm{pyF})_{2}\right]} \\
(3)\end{array}$ & {$\left[\begin{array}{c}\left.\mathrm{Mn}(\mathrm{tfpb})_{2}(\mathrm{MeOH})_{2}\right] \\
(4)\end{array}\right.$} \\
\hline Formula & $\mathrm{C}_{30} \mathrm{H}_{22} \mathrm{~F}_{6} \mathrm{MnN}_{2} \mathrm{O}_{6}$ & $\mathrm{C}_{30} \mathrm{H}_{22} \mathrm{~F}_{6} \mathrm{MnN}_{2} \mathrm{O}_{8}$ & $\mathrm{C}_{30} \mathrm{H}_{20} \mathrm{~F}_{8} \mathrm{MnN}_{2} \mathrm{O}_{4}$ & $\mathrm{C}_{22} \mathrm{H}_{20} \mathrm{~F}_{6} \mathrm{MnO}_{6}$ \\
\hline$M_{\mathrm{r}}$ & 675.43 & 707.43 & 679.42 & 549.32 \\
\hline$T(\mathrm{~K})$ & $293(2)$ & $293(2)$ & $150(2)$ & $293(2)$ \\
\hline Crystal system & Monoclinic & Triclinic & Monoclinic & Triclinic \\
\hline Space group & $P 2_{1} / n$ & $P-1$ & $P 2_{1} / c$ & $P-1$ \\
\hline$a(\AA)$ & $16.1805(3)$ & $7.3146(2)$ & $11.8720(3)$ & $10.4921(4)$ \\
\hline$b(\AA)$ & $10.5318(2)$ & $9.9367(2)$ & $8.8105(2)$ & $10.5763(4)$ \\
\hline$c(\AA)$ & $17.8217(3)$ & $10.7440(2)$ & $14.5507(4)$ & $12.4197(5)$ \\
\hline$\alpha\left(^{\circ}\right)$ & 90 & $108.132(2)$ & 90 & $70.893(2)$ \\
\hline$\beta\left(^{\circ}\right)$ & $91.558(2)$ & $100.589(2)$ & $108.628(3)$ & $66.685(2)$ \\
\hline$\gamma\left({ }^{\circ}\right)$ & 90 & $91.833(2)$ & 90 & $82.624(2)$ \\
\hline Volume $\left(\AA^{3}\right)$ & $3035.87(10)$ & $726.16(3)$ & $1442.24(7)$ & $1195.92(8)$ \\
\hline$Z$ & 4 & 1 & 2 & 2 \\
\hline$D_{\text {calc }}\left(\mathrm{Mg} / \mathrm{m}^{3}\right)$ & 1.478 & 1.618 & 1.565 & 1.525 \\
\hline$\mu\left(\mathrm{mm}^{-1}\right)$ & 0.517 & 0.549 & 0.549 & 0.634 \\
\hline$F(000)$ & 1372.0 & 359.0 & 686.0 & 558.0 \\
\hline Crystal size (mm) & $0.5 \times 0.2 \times 0.1$ & $0.6 \times 0.6 \times 0.5$ & $0.2 \times 0.2 \times 0.05$ & $0.25 \times 0.1 \times 0.03$ \\
\hline Reflections collected & 28841 & 5959 & 13789 & 9395 \\
\hline Data/restraints/parameters & $6949 / 2 / 471$ & $3298 / 2 / 220$ & $3311 / 0 / 205$ & $5457 / 2 / 353$ \\
\hline$R_{\text {int }}$ & 0.0322 & 0.0133 & 0.0333 & 0.0291 \\
\hline$R, w R_{2}[\mathrm{I}>2 \sigma(I)]^{\mathrm{a}}$ & $0.0416,0.1040$ & $0.0328,0.0882$ & $0.0399,0.0961$ & $0.0459,0.1073$ \\
\hline$R, w R_{2}(\text { all data })^{\mathrm{b}}$ & $0.0650,0.1162$ & $0.0352,0.0904$ & $0.0529,0.1037$ & $0.0812,0.1264$ \\
\hline GOF, $S^{c}$ & 1.051 & 1.074 & 1.044 & 1.012 \\
\hline $\operatorname{Max} / \min \Delta \rho\left(\mathrm{e} / \AA^{3}\right)$ & $0.21 /-0.21$ & $0.31 /-0.34$ & $0.83 /-0.27$ & $0.32 /-0.27$ \\
\hline
\end{tabular}

${ }^{\mathrm{a}} R=\Sigma|| F_{\mathrm{o}}|-| F_{\mathrm{c}}|| \Sigma\left|F_{\mathrm{o}}\right| \cdot{ }^{\mathrm{b}} w R_{2}=\left\{\Sigma\left[w\left(F_{\mathrm{o}}{ }^{2}-F_{\mathrm{c}}{ }^{2}\right)^{2}\right] / \Sigma\left[w\left(F_{\mathrm{o}}{ }^{2}\right)^{2}\right]\right\}^{1 / 2} \cdot{ }^{\mathrm{c}} S=\left\{\Sigma\left[\left(F_{\mathrm{o}}{ }^{2}-F_{\mathrm{c}}{ }^{2}\right)^{2}\right] /(n / p)\right\}^{1 / 2}$ where $n$ is the number of reflections and $p$ is the total number of parameters refined.

$\left[\mathrm{Mn}(\mathrm{tfpb})_{2}\left(\mathrm{H}_{2} \mathrm{O}\right)_{2}\right]$ and the corresponding heteroaromatic ligands pyridine-4-on (pyon) and 3-hydroxypyridine-2-on (hpyon) in 1:2 molar ratio in warm ethanol or acetone, respectively. Compound 3 was prepared by the reaction of $\left[\mathrm{Mn}(\mathrm{tfpb})_{2}\left(\mathrm{H}_{2} \mathrm{O}\right)_{2}\right]$ in warm 1-fluoropyridine (pyF) acting as a solvent and as a ligand. Crystals suitable for $\mathrm{X}$-ray analyses were obtained by slow evaporation of the solvent at room temperature over a few days. The IR spectrum of 1 shows two bands at 3244 and $3080 \mathrm{~cm}^{-1}$ and the spectrum of 2 two bands at 3251 and $3120 \mathrm{~cm}^{-1}$ that suggest the involvement of the $\mathrm{O}-\mathrm{H}$ and $\mathrm{N}-\mathrm{H}$ groups of pyridone ligands in strong hydrogen bonding. The spectrum of $\mathbf{4}$ shows one broad band at $3381 \mathrm{~cm}^{-1}$ that suggests the involvement of the $\mathrm{O}-\mathrm{H}$ groups of methanol ligands in strong hydrogen bonding. In all four compounds, there are bands in the frequency range $1609-1527 \mathrm{~cm}^{-1}$ characteristic for the $v(\mathrm{C}=\mathrm{O})$ and $v(\mathrm{C}=\mathrm{C})$ stretching of the tfpb ligand.

Compound 1 crystallizes in the monoclinic $P 2_{1} / n$ space group. Selected bond distances and angles of $\mathbf{1}$ are summarized in Table 2. The asymmetric unit contains two crystallographically independent half-molecules (A and $\mathrm{B})$, with both independent $\mathrm{Mn}^{\mathrm{II}}$ atoms sitting on the inversion centers. Both manganese(II) atoms are octahedrally coordinated (Fig. 1). In the equatorial plane, both metal centers are surrounded by four oxygen atoms of two che- lating tfpb ligands in a trans arrangement, with $\mathrm{Mn}-\mathrm{O}$ distances 2.1365(14) and 2.1233(13) $\AA$ (for A) and 2.1245(13) and 2.1467(13) $\AA$ (for B). The $\mathrm{Mn}(\mathrm{tfpb})_{2}$ fragments deviate from planarity, the angle between the mean plane formed by the equatorial $\mathrm{MnO}_{4}$ core and that of the tfpb chelate $\mathrm{C}_{3} \mathrm{O}_{2}$ moiety being $14.48(6)$ and $16.47(6)^{\circ}$. In both complexes the axial positions are occupied by two pyon ligands bonded to the metal center through the $\mathrm{O}$ atom, with $\mathrm{Mn} 1-\mathrm{O} 3$ distance of 2.2358(12) $\AA$ and Mn1-O3-C23 angle of $131.10(11)^{\circ}$ and Mn2-O6 distance of 2.2035(12) $\AA$ and Mn2-O6-C28 angle of $126.58(11)^{\circ}$. These distances are similar to those reported for the three known Mn complexes with tfpb. ${ }^{10}$ The pyon ligands are inclined toward the tfpb moiety. The angle between the plane of the pyon ring and the plane of the equatorial $\mathrm{MnO}_{4}$ core deviates from $90^{\circ}$ being $78.60(5)^{\circ}$ (for A) and only $44.51(5)^{\circ}$ (for B). Superposition of both complexes shows that pyon ligands are oriented in the opposite direction (Fig. 2) with pyon ring in complex $\mathrm{B}$ inclined toward the phenyl ring of the $\mathrm{tfpb}$ ligand. Complex $\mathrm{A}$ is stabilized by an intramolecular $\mathrm{C} 22-\mathrm{H} 22 \cdots \mathrm{O} 2^{\mathrm{i}}$ interaction between pyon and tfpb ligand (Table 3) and $\mathrm{C} 1-\mathrm{F} 3 \mathrm{a} / \mathrm{b} \cdots \pi$ interactions between $-\mathrm{CF}_{3}$ group and pyon ring with F...Cg3 distances of 3.769(10) and $3.82(4) \AA$ and $\mathrm{C}-\mathrm{F} \cdots \mathrm{Cg} 3$ angles of $130.4(5)$ and $128(3)^{\circ}$, respectively, where $\mathrm{Cg} 3$ is $\mathrm{N} 1 / \mathrm{C} 21-\mathrm{C} 25$ ring centroid (Fig. 3). Complex B is stabilized by an intramolecular 


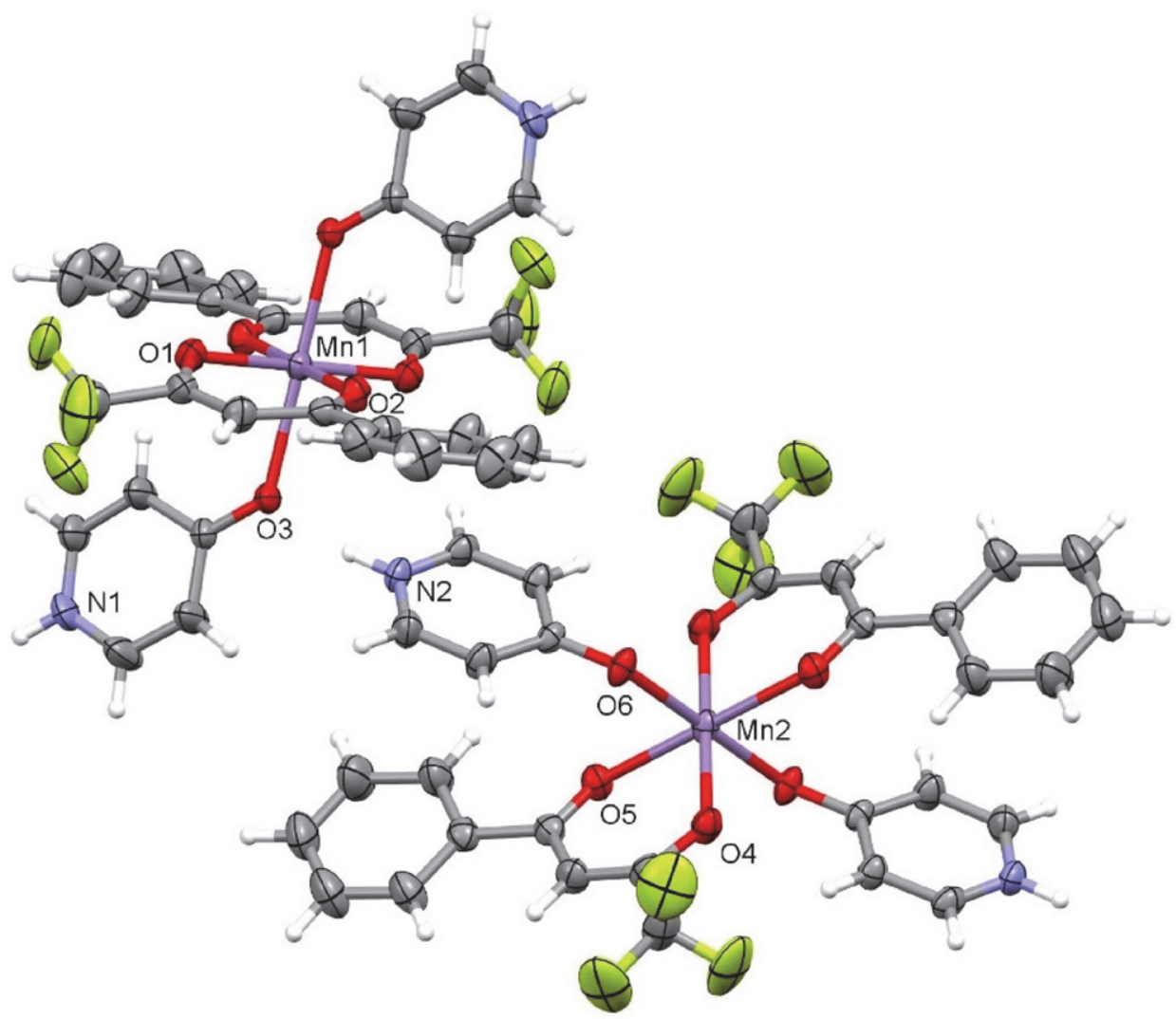

Figure 1. Crystallographically independent molecules in $\mathbf{1}$. Disorder on $\mathrm{CF}_{3}$ groups has been omitted for clarity. Displacement ellipsoids are drawn at $30 \%$ probability level.

$\mathrm{C} 27-\mathrm{H} 27 \cdots \mathrm{O} 4^{\mathrm{ii}}$ interaction between pyon and tfpb ligand. The NH groups of the pyon ligands of both independent complexes act as hydrogen-bond donors interacting with the tfpb carbonyl oxygens of the adjacent complexes, facilitating the formation of a hydrogen-bonded tree-dimensional supramolecular structure (Fig. 3). Complex A inter-

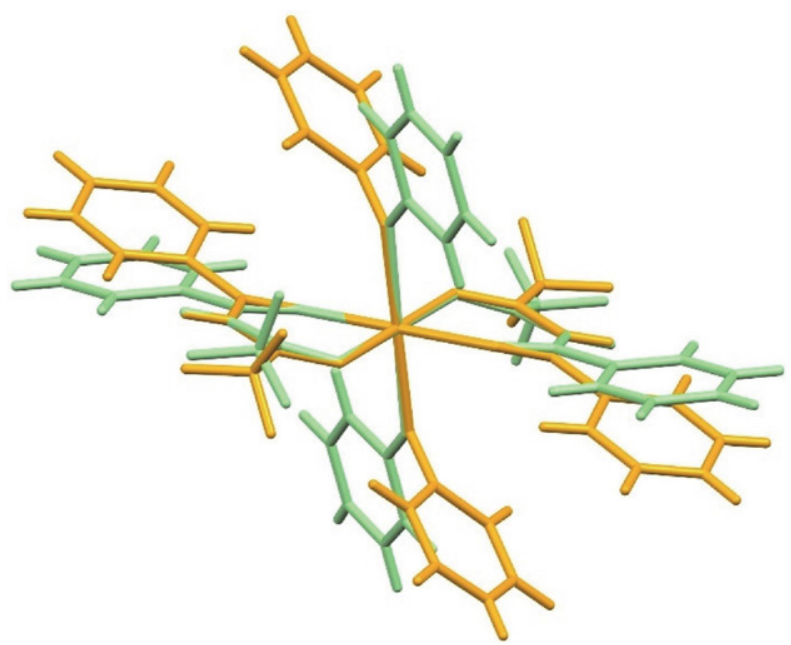

Figure 2. Superposition of crystallographically independent molecules $\mathrm{A}$ (green) and $\mathrm{B}$ (orange) in $\mathbf{1}$. Disorder on $\mathrm{CF}_{3}$ groups has been omitted for clarity. acts with two complexes B through $\mathrm{N} 1-\mathrm{H} 1 \cdots \mathrm{O} 6^{i i i}$ bonding enabling the formation of an $\mathrm{ABAB}$ chain. Complex $\mathrm{B}$ interacts with two complexes A through $\mathrm{N} 2-\mathrm{H} 2 \cdots \mathrm{O} 3$ bonding enhanced by $\mathrm{C} 26-\mathrm{H} 26 \cdots \mathrm{O}^{\mathrm{i}}$ interaction with $\mathrm{R}_{2}{ }_{2}(7)$ ring motif ${ }^{11}$ enabling the formation of an $\mathrm{ABAB}$ chain in the second dimension. Furthermore, complex B interacts with two adjacent complexes $\mathrm{B}$ through the centrosymmetric C29-H29...F6a ${ }^{\text {iv }}$ interactions with $\mathrm{R}_{2}{ }_{2}(18)$ ring motif forming a BBB chain in the third dimension (Table 3 ).

Table 2. Selected bond distances and angles for $\mathbf{1}$.

\begin{tabular}{llll}
\hline Distance & $(\AA)$ & & \\
\hline Mn1-O1 & $2.1365(14)$ & Mn2-O4 & $2.1245(13)$ \\
Mn1-O2 & $2.1233(13)$ & Mn2-O5 & $2.1467(13)$ \\
Mn1-O3 & $2.2358(12)$ & Mn2-O6 & $2.2035(12)$ \\
\hline Angle & $\left(^{\circ}\right)$ & & \\
\hline O1-Mn1-O2 & $84.10(5)$ & O4-Mn2-O5 & $85.38(5)$ \\
O1-Mn1-O2 & $95.90(5)$ & O4-Mn2-O5 & $94.62(5)$ \\
O1-Mn1-O3 & $85.43(5)$ & O4-Mn2-O6 & $85.82(5)$ \\
O1-Mn1-O3 & $94.57(5)$ & O4-Mn2-O66 & $94.18(5)$ \\
O2-Mn1-O3 & $86.91(5)$ & O5-Mn2-O6 & $85.20(5)$ \\
O2-Mn1-O3 $^{\mathrm{i}}$ & $93.09(5)$ & O5-Mn2-O6 & $94.80(5)$ \\
\hline
\end{tabular}

Symmetry codes: (i) $1-x,-y,-z$; (ii) $1-x,-y, 1-z$. 
a)

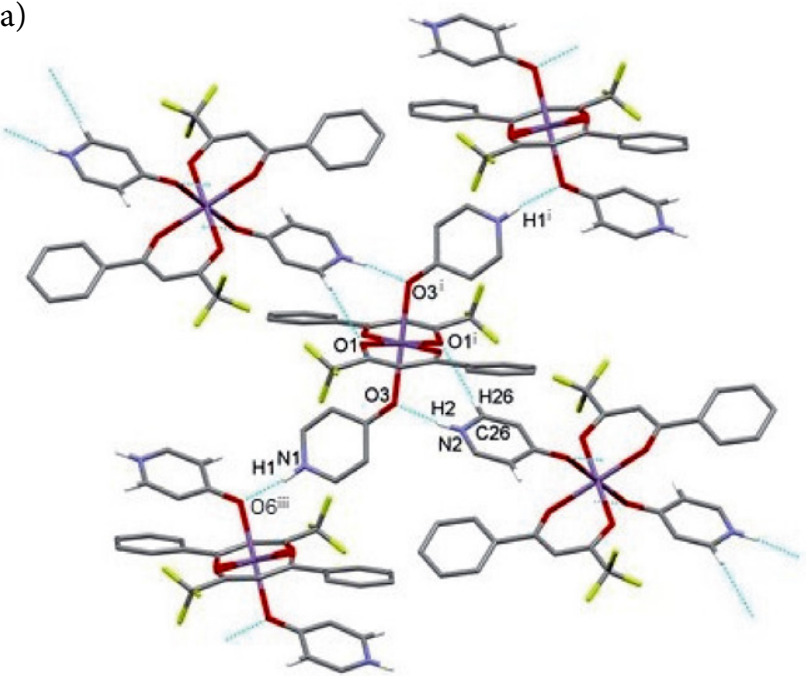

b)

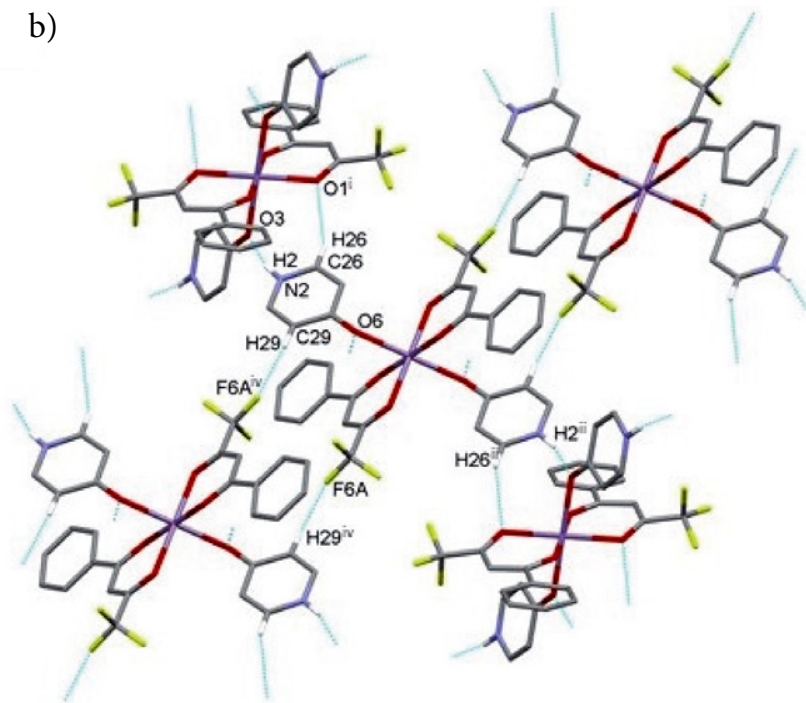

Figure 3. Three-dimensional supramolecular structure in $\mathbf{1}$ is achieved by hydrogen bonding around a) molecule A and b) molecule B through a series of $\mathrm{N} 1-\mathrm{H} 1 \cdots \mathrm{O} 6^{\mathrm{iii}}, \mathrm{N} 2-\mathrm{H} 2 \cdots \mathrm{O} 3, \mathrm{C} 26-\mathrm{H} 26 \cdots \mathrm{O} 1^{\mathrm{i}}$ and $\mathrm{C} 29-\mathrm{H} 29 \cdots \mathrm{F}^{\text {iv }}{ }^{\text {iv }}$ interactions. Blue dashed lines indicate hydrogen bonds. For the sake of clarity, intramolecular interactions, disorder on $\mathrm{CF}_{3}$ groups and $\mathrm{H}$ atoms not involved in the motif shown have been omitted. For symmetry codes see Table 3.

Table 3. Hydrogen bonds for 1-4 [A and $\left.{ }^{\circ}\right]$

\begin{tabular}{|c|c|c|c|c|}
\hline D-H $\cdots A$ & d(D-H) & $\mathbf{d}(\mathbf{H} \cdots \mathbf{A})$ & d(D..A) & $<(\mathrm{DHA})$ \\
\hline \multicolumn{5}{|l|}{1} \\
\hline $\mathrm{N} 1-\mathrm{H} 1 \cdots \mathrm{O}^{\mathrm{iii}}$ & $0.872(17)$ & $1.854(17)$ & $2.720(2)$ & $172(3)$ \\
\hline $\mathrm{N} 2-\mathrm{H} 2 \cdots \mathrm{O} 3$ & $0.888(16)$ & $1.859(17)$ & $2.723(2)$ & $164(2)$ \\
\hline $\mathrm{C} 22-\mathrm{H} 22 \cdots \mathrm{O} 2^{\mathrm{i}}$ & 0.93 & 2.36 & $3.119(3)$ & 139.1 \\
\hline $\mathrm{C} 26-\mathrm{H} 26 \cdots \mathrm{O} 1^{\mathrm{i}}$ & 0.93 & 2.48 & $3.322(2)$ & 151.1 \\
\hline $\mathrm{C} 27-\mathrm{H} 27 \ldots \mathrm{O} 4^{\mathrm{ii}}$ & 0.93 & 2.47 & $3.206(2)$ & 136.6 \\
\hline $\mathrm{C} 29-\mathrm{H} 29 \ldots \mathrm{F} 6 \mathrm{a}^{\mathrm{iv}}$ & 0.93 & 2.47 & $3.394(7)$ & 175.7 \\
\hline \multicolumn{5}{|l|}{2} \\
\hline $\mathrm{O} 4-\mathrm{H} 4 \cdots^{-\mathrm{O}} 1^{\mathrm{i}}$ & $0.814(17)$ & $1.952(18)$ & $2.7495(16)$ & $166(3)$ \\
\hline $\mathrm{N} 1-\mathrm{H} 1 \cdots \mathrm{O} 3^{\mathrm{ii}}$ & $0.882(14)$ & $2.009(15)$ & $2.8829(15)$ & $170.2(18)$ \\
\hline $\mathrm{C} 13-\mathrm{H} 13 \cdots \mathrm{O} 4^{\mathrm{iii}}$ & 0.93 & 2.58 & $3.4770(19)$ & 162.9 \\
\hline $\mathrm{C} 15-\mathrm{H} 15 \cdots \mathrm{O} 2^{\mathrm{iv}}$ & 0.93 & 2.42 & $3.2428(19)$ & 147.3 \\
\hline \multicolumn{5}{|l|}{3} \\
\hline $\mathrm{C} 13-\mathrm{H} 13 \cdots \mathrm{F} 2^{\mathrm{ii}}$ & 0.95 & 2.42 & $3.287(3)$ & 151.6 \\
\hline $\mathrm{C} 14-\mathrm{H} 14 \cdots \mathrm{O} 1^{\mathrm{iii}}$ & 0.95 & 2.58 & $3.493(3)$ & 161.3 \\
\hline \multicolumn{5}{|l|}{4} \\
\hline $\mathrm{O} 5-\mathrm{H} 5 \cdots \mathrm{O} 1^{\mathrm{i}}$ & $0.822(10)$ & $1.966(14)$ & $2.772(2)$ & $167(4)$ \\
\hline $\mathrm{O} 6-\mathrm{H} 6 \cdots \mathrm{O}^{\mathrm{ii}}$ & $0.813(10)$ & $2.001(13)$ & $2.801(2)$ & $168(4)$ \\
\hline
\end{tabular}

Symmetry codes for 1: (i) $1-x,-y,-z$; (ii) $1-x,-y, 1-z$; (iii) $-1 / 2+$

$x, 1 / 2-y,-1 / 2+z$; (iv) $1-x, 1-y, 1-z$; for 2 : (i) $2-x, 2-y,-z$; (ii) 1

$-x, 2-y,-z$; (iii) $2-x, 2-y, 1-z$; (iv) $-1+x, y, z$; for 3 : (ii) $-x, 1$

$-y,-z$; (iii) $x, 1 / 2-y, 1 / 2+z$; for 4 : (i) $2-x, 1-y, 1-z$; (ii) $2-x,-y$,

$1-z$.

The supramolecular structure is further stabilized also by C11-F4a $\cdots \pi$ interaction between $-\mathrm{CF}_{3}$ group of complex $\mathrm{B}$ and pyon ring of complex A with $\mathrm{F}$... Cg3 distance of 3.806(11) $\AA$ and C-F ...Cg3 angle of 139.1(5) .

Compound 2 crystallizes in the triclinic $P-1$ space group. Selected bond distances and angles are summarized in Table 4 . The asymmetric unit contains one half of the complex, with the $\mathrm{Mn}^{\mathrm{II}}$ atom sitting on the inversion center. Octahedrally coordinated manganese(II) atom is surrounded by four oxygen atoms positioned in the equatorial plane, stemming from two chelating tfpb ligands in a trans arrangement, with $\mathrm{Mn}-\mathrm{O}$ distances $2.1132(10)$ and 2.1218(9) $\AA$ (Fig. 4). The Mn(tfpb) ${ }_{2}$ fragment deviates from planarity, the angle between the mean plane formed by the equatorial $\mathrm{MnO}_{4}$ core and that of the tfpb chelate $\mathrm{C}_{3} \mathrm{O}_{2}$ moiety being $15.91(4)^{\circ}$. The axial positions are occupied by two hpyon ligands bonded to the metal center through the $\mathrm{O} 3$ atom, with $\mathrm{Mn} 1-\mathrm{O} 3$ distance of 2.2768(10) $\AA$ and Mn1-O3-C11 angle of 128.19(9) . The hpyon ligand is inclined toward the tfpb moiety, with the angle between the plane of the hpyon ring and that of the equatorial $\mathrm{MnO}_{4}$ core being $43.25(6)^{\circ}$. The hydroxy group of the hpyon ligand is involved in intramolecular hydrogen bonding with the tfpb ligand through $\mathrm{O} 4-\mathrm{H} 4 \cdots \mathrm{O} 1^{\mathrm{i}}$ interaction (Table 3). The NH group of the hpyon ligand acts as a hydrogen bond donor, facilitating the formation of a centrosymmetric hydrogen-bonded motif via N1$\mathrm{H} 1 \cdots{ } 3^{\text {ii }}$ interactions with the ligated carbonyl $\mathrm{O} 3$ atom enhanced by $\mathrm{C} 15-\mathrm{H} 15 \cdots \mathrm{O} 2^{\text {iv }}$ interactions with the graphset motifs $\mathrm{R}_{2}{ }_{2}(8)$ and $\mathrm{R}_{2}{ }_{2}(7)$, respectively (Fig. 5 and Table $3)$. This interaction is further stabilized by $\mathrm{C} 1-\mathrm{F} 3 \cdots \pi$ interaction between $\mathrm{CF}_{3}$ group and the hpyon ring with $d(\mathrm{~F} 3 \cdots C g 3)=3.2278(17) \AA$ and $<(\mathrm{C} 1-\mathrm{F} 3 \cdots C g 3)=$ $135.64(11)^{\circ}$, where $C g 3$ is $\mathrm{N} 1 / \mathrm{C} 11-\mathrm{C} 15$ ring centroid. Consequently, a chain is formed along the $a$ axis. The chains are further connected into layers along the $a c$ plane via centrosymmetric $\mathrm{C} 13-\mathrm{H} 13 \cdots \mathrm{O} 4^{\mathrm{iii}}$ hydrogen bonding between hpyon $\mathrm{CH}$ moiety and the hydroxy group of the adjacent molecule (Fig. 5). There are no significant $\pi \cdots \pi$ interactions. 


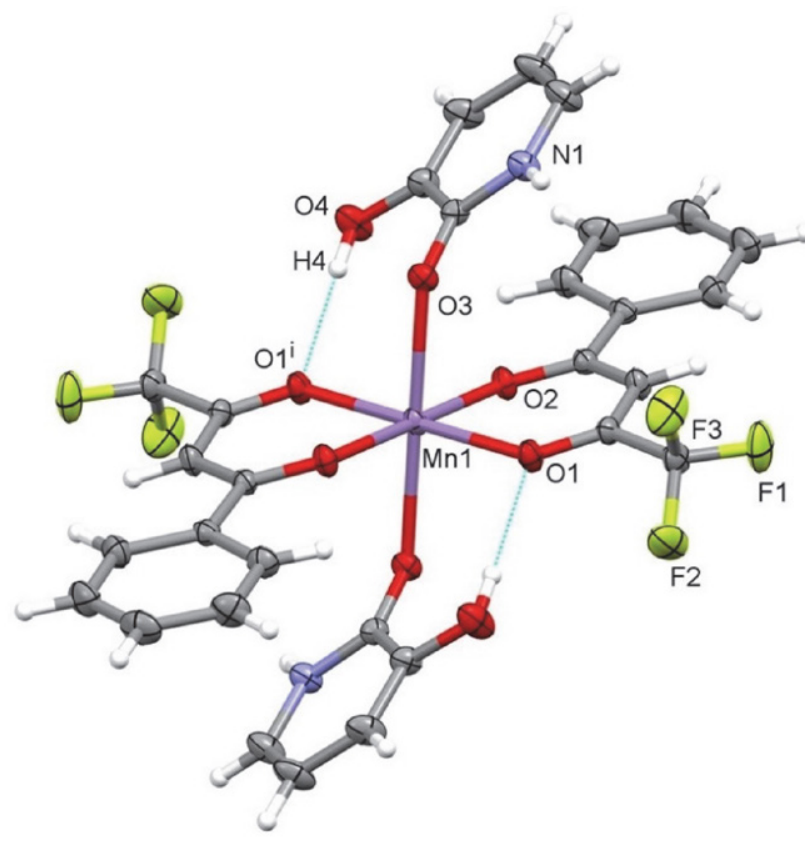

Figure 4. Structure of 2. Displacement ellipsoids are drawn at the $30 \%$ probability level. Intramolecular hydrogen bonding is presented by dashed blue lines.

Table 4. Selected bond distances and angles for $\mathbf{2}$.

\begin{tabular}{llll}
\hline Distance & $(\AA)$ & & \\
\hline Mn1-O1 & $2.1132(10)$ & Mn1-O2 & $2.1218(9)$ \\
Mn1-O3 & $2.2768(10)$ & & \\
\hline Angle & $\left(^{\circ}\right)$ & & \\
\hline O1-Mn1-O2 & $84.24(4)$ & O1-Mn1-O2 & \\
O1-Mn1-O3 & $92.67(4)$ & O1-Mn1-O3 & 95.76(4) \\
O2-Mn1-O3 & $84.40(4)$ & O2-Mn1-O3 & $95.63(4)$ \\
\hline
\end{tabular}

Symmetry code: (i) $2-x, 2-y,-z$.

In the solid state, pyridin-4-one and 3-hydroxypyridin-2-one are in the lactam form. ${ }^{12,13}$ Also in metal complexes the lactam form of both predominates. A search of the Cambridge Structural Database (CSD, Version 5.41, plus updates $)^{14}$ has revealed 26 entries ${ }^{15}$ of metal complexes where pyridin-4-one, in its lactam form, is bonded via $\mathrm{O}$ atom also observed in complex $\mathbf{1}$. However, 9 entries with the lactim form (as 4-hydroxypyridine) bonded via $\mathrm{N}$ atom were found in the CSD with Re, Ir, Pt, and $\mathrm{Ag}^{16}$ as well as $\mathrm{Cu}$ and $\mathrm{Fe} .{ }^{17}$ This observation can be explained by the Pearson HSAB (hard-soft acid-base) concept ${ }^{18}$ since soft acids, such as Re, Ir, Pt, and Ag, show a preference for bonding via pyridine $\mathrm{N}$ atom (an intermediate base) as opposed to the - $\mathrm{OH}$ group (a hard base). Additionally, 3 entries with the lactim form bonded via $\mathrm{OH}$ group were also found with $\mathrm{Nd}, \mathrm{Tb}, \mathrm{Dy} .{ }^{19}$ In metal complexes with 3-hydroxypyridin-2-on lactam form with monodentate ligation via $\mathrm{O}$ atom ${ }^{20,21}$ was found in 9 entries; the same type was also observed in complex 2. Additionally, 3 entries were found with $O, O^{\prime}$-chelating ligation. ${ }^{21,22}$ However, no entries were found with lactim form (as 2,3-dihydroxypyridine) bonded to the metal center. For comparison, metal complexes with pyridine-2-one were more often investigated than complexes with pyridin-4-one and 3-hydroxypyridin-2-one and a variety of coordination modes has been observed. ${ }^{21,23,24}$

Compound 3 crystallizes in the monoclinic $P 2_{1} / c$ space group. Selected bond distances and angles of $\mathbf{3}$ are summarized in Table 5. Initial attempts to collect XRD data at room temperature failed due to slow decomposition of the crystal when exposed to the air. Most probably 1-fluoropyridine molecule is eliminated from the complex and the crystal lattice is being thus destroyed. Similar loss of pyridine bonded in zinc picolinato complexes has been previously observed. ${ }^{61,62}$ The asymmetric unit contains one half of the complex, with the $\mathrm{Mn}^{\mathrm{II}}$ atom sitting on the inversion center. The manganese(II) atom in compound 3 is octahedrally coordinated (Fig. 6). In the equatorial plane, $\mathrm{Mn}^{\mathrm{II}}$ atom is surrounded by four oxygen atoms stemming from the two chelating tfpb ligands, being in a trans arrangement, with $\mathrm{Mn}-\mathrm{O}$ distances 2.1415(14) and 2.1337(14) $\AA$. The $\mathrm{Mn}(\mathrm{tfpb})_{2}$ fragment deviates from planarity, the angle between the mean plane formed by the $\mathrm{MnO}_{4}$ core and that of the tfpb chelate $\mathrm{C}_{3} \mathrm{O}_{2}$ moiety being $18.00(7)^{\circ}$. The axial positions are occupied by two pyF ligands bonded to the metal center through the $\mathrm{N} 1$ atom, with Mn1-N1 distance of 2.3425(17) A. PyF ligand plays the main role in the formation of a layered structure due to the absence of the competing strong hydrogen bond donors. As a hydrogen bond donor PyF is involved in C14-H14 $\cdots \mathrm{O} 1^{\text {iii }}$ interaction with carbonyl oxygen atom and in centrosymmetric $\mathrm{C} 13-\mathrm{H} 13 \cdots \mathrm{F} 2^{\mathrm{ii}}$ interactions with fluorine atom of $-\mathrm{CF}_{3}$ group of tfpb ligands of the adjacent complexes (Fig. 7 and Table 3). Thus, each complex is involved in eight hydrogen bonds with six adjacent complexes forming a layered structure. 2D structure is supported by centrosymmetric $\pi \cdots \pi$ interactions between adjacent pyF rings with centroid-to-centroid distance of 3.9403(14) $\AA$, perpendicular distance between rings of 3.2624(10) $\AA$ and ring slippage of $2.210 \AA$. Layered structure is further supported also by $\mathrm{C}-\mathrm{F} \cdots \pi$ interactions between $\mathrm{pyF}$ fluorine atom and $\mathrm{pyF}$ aromatic ring with $d(\mathrm{~F} 4 \cdots C g 3)=3.6714(19) \AA$ and $<(\mathrm{C} 11-\mathrm{F} 4 \cdots C g 3)=$ $75.63(13)^{\circ}$ as well as by interactions between $-\mathrm{CF}_{3}$ group and benzene ring of $\mathrm{tfpb}$ ligand with $d(\mathrm{~F} 2 \cdots \mathrm{Cg} 4)=3.715(2)$ $\AA$ and $<(\mathrm{C} 1-\mathrm{F} 2 \cdots C g 4)=126.72(15)^{\circ}$, where $C g 3$ and $C g 4$ are $\mathrm{N} 1 / \mathrm{C} 11-\mathrm{C} 15$ and $\mathrm{C} 5-\mathrm{C} 10$ ring centroids, respectively (Fig. 7).

The inclination of pyon and hpyon ligands toward the tfpb moiety in $\mathbf{1}$ and $\mathbf{2}$ is best compared with the compound 3 since the ligation of pyF via $\mathrm{N}$ atom cannot enable much deviation in comparison to the pyon and hpyon ligands bonded via $\mathrm{O}$ atom. Superposition of both crystallographically independent molecules in $\mathbf{1}$ as well as mole- 
a)
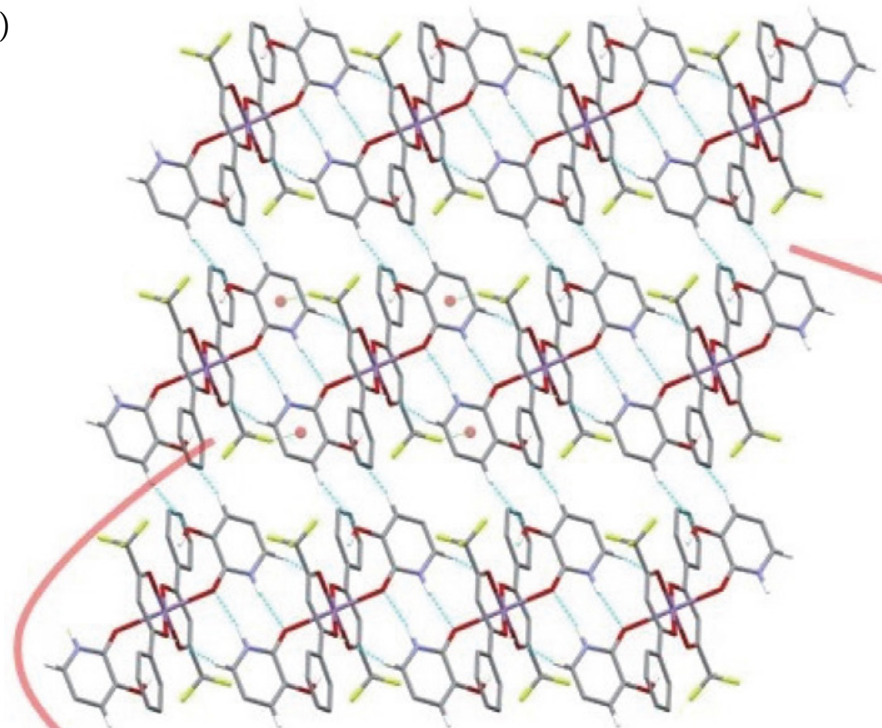

b)

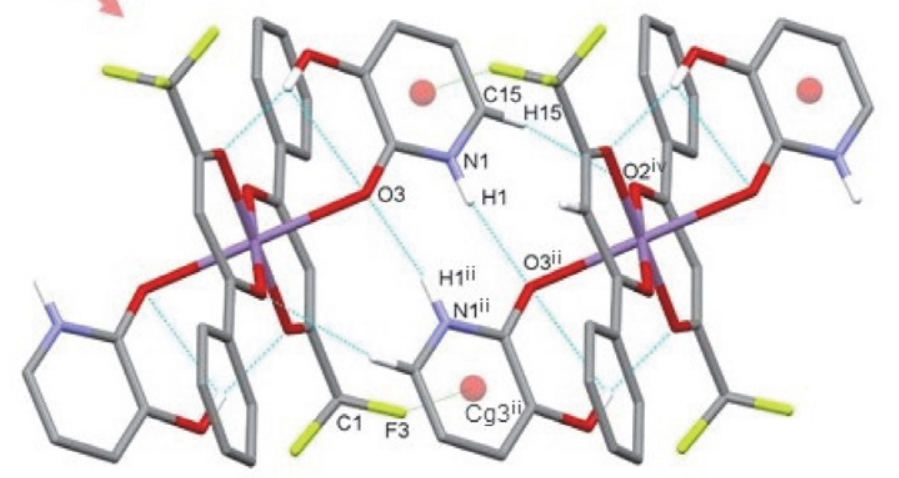

c)
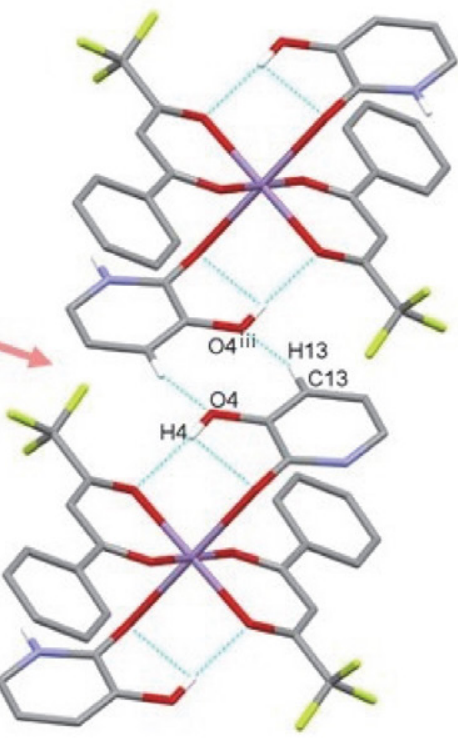

d)

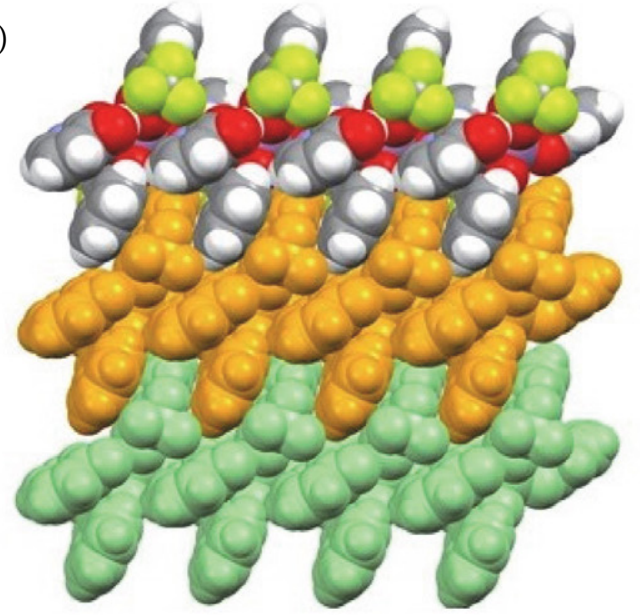

Figure 5. a) Hydrogen-bonded layer along the ac plane in 2 is formed by b) centrosymmetric $\mathrm{N} 1-\mathrm{H} 1 \cdots \mathrm{O} 3^{\mathrm{ii}}, \mathrm{C} 15-\mathrm{H} 15 \cdots \mathrm{O} 2^{\mathrm{iv}}$ and $\mathrm{C} 1-\mathrm{F} 3 \cdots \mathrm{Cg} 3^{\mathrm{ii}}$ interactions and c) $\mathrm{C} 13-\mathrm{H} 13 \cdots \mathrm{O} 44^{\mathrm{iii}}$ interactions; d) packing of layers (arbitrary colors). Blue and green dashed lines indicate hydrogen bonds and C-F $\cdots \pi$ interactions, respectively. For the sake of clarity, $\mathrm{H}$ atoms not involved in the motif shown have been omitted. For symmetry codes see Table 3.

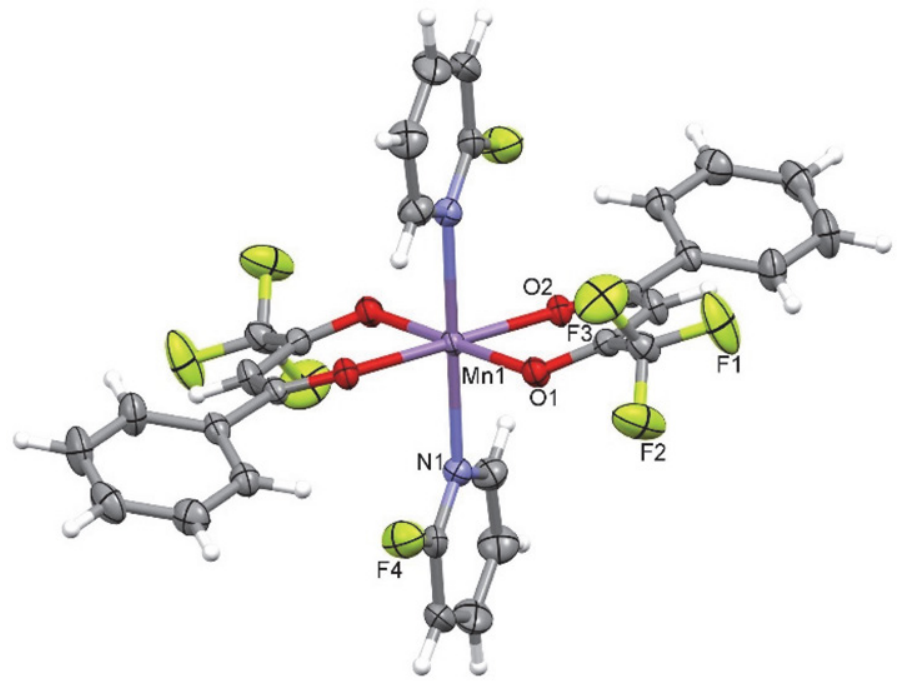

Figure 6. Structure of 3. Displacement ellipsoids are drawn at 50\% probability level. 


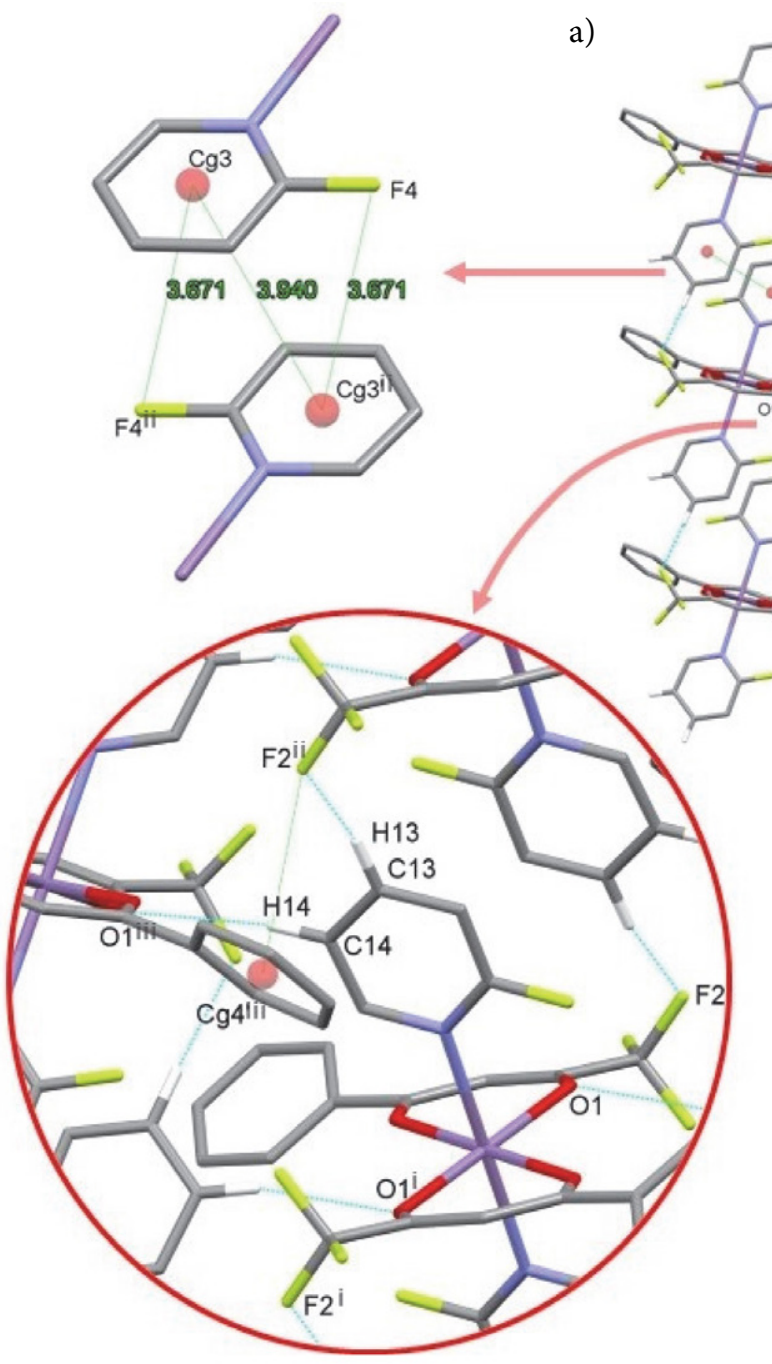

Figure 7. a) Hydrogen-bonded layer along the ac plane in 3 is formed by $\mathrm{C} 13-\mathrm{H} 13 \cdots \mathrm{O} 1^{\mathrm{iii}}$ and centrosymmetric $\mathrm{C} 14-\mathrm{H} 14 \cdots \mathrm{F} 2^{\mathrm{ii}}$ interactions as well as centrosymmetric $\pi \cdots \pi$ interactions and C-F $\cdots \pi$ interactions; b) packing of layers (arbitrary colors). Blue and green dashed lines indicate hydrogen bonds and $\pi \cdots \pi$ and C-F $\cdots \pi$ interactions, respectively. For the sake of clarity, $\mathrm{H}$ atoms not involved in the motif shown have been omitted. For symmetry codes see Table 3 .

Table 5. Selected bond distances and angles for 3 .

\begin{tabular}{llll}
\hline Distance & $(\AA)$ & & \\
\hline Mn1-N1 & $2.3425(17)$ & Mn1-O1 & $2.1415(14)$ \\
Mn1-O2 & $2.1337(14)$ & & \\
\hline Angle & $\left(^{\circ}\right)$ & & \\
\hline N1-Mn1-O1 & $94.36(6)$ & N1-Mn1-O1 & $85.64(6)$ \\
N1-Mn1-O2 & $88.31(6)$ & N1-Mn1-O2 & $91.69(6)$ \\
O1-Mn1-O2 & $85.12(5)$ & O1-Mn1-O2 & $94.88(5)$ \\
\hline
\end{tabular}

Symmetry code: (i) $-x,-y,-z$.

cules $\mathbf{2}$ and 3 is presented in Fig. 8. Pyon and hpyon ligands are inclined toward the tfpb moiety by $78.60(5)^{\circ}$ (molecule $\mathrm{A}$ in $\mathbf{1}$ ), 44.51(5) $)^{\circ}$ (molecule B in $\mathbf{1}$ ) and $43.25(6)^{\circ}(2)$ representing a substantial deviation from $90^{\circ}$. However, in the case of molecule B in $\mathbf{1}$ and molecule $\mathbf{2}$ also the phenyl rings of tfpb are evidently inclined toward pyridone moieties.

Compound 4 crystallizes in the triclinic $P-1$ space group. Selected bond distances and angles of 4 are summarized in Table 6 . The asymmetric unit contains one complex molecule with cis-octahedral arrangement of methanol ligands on the manganese(II) central atom (Fig. 9). Two methanol ligands are bonded to the metal center with Mn1-O5 and Mn1-O6 distances of 2.1714(18) and 2.173(2) $\AA$, respectively, and O5-Mn1-O6 angle of $88.54(8)^{\circ}$. The Mn1-O bond lengths with four oxygen atoms of the two chelating tfpb ligands are asymmetric with the longer ones of 2.1821(18) and 2.1751(17) $\AA$ at the trifluoromethyl substituent and the shorter ones of 2.1266(18) and 2.1315(18) $\AA$ at the phenyl substituent. The Mn(tfpb) fragments deviate from planarity, the tfpb ligands being in- 

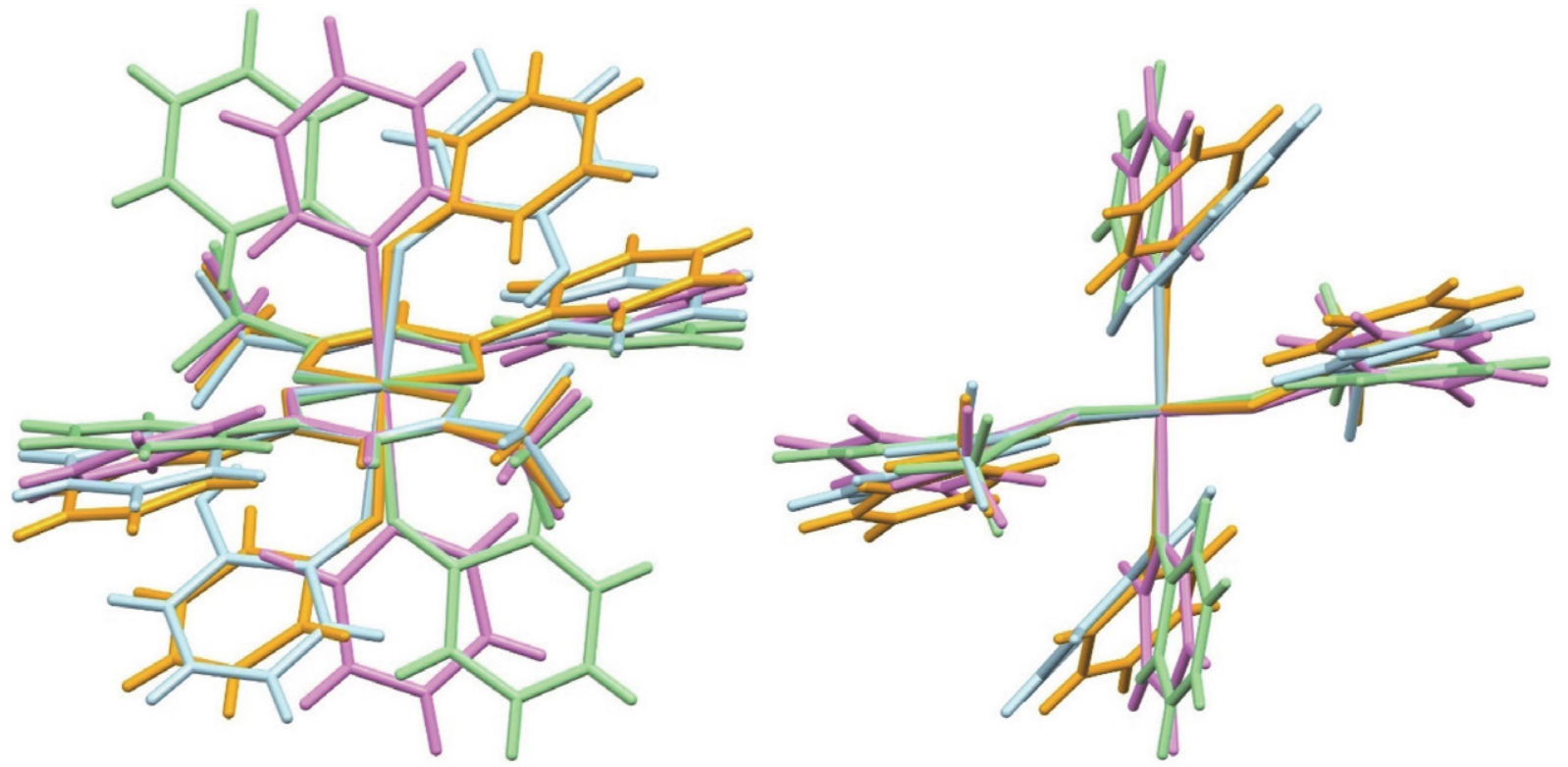

Figure 8. Two views on superposition of crystallographically independent molecules A (green) and B (orange) in 1, 2 (blue) and 3 (violet). Disorder on $\mathrm{CF}_{3}$ groups has been omitted for clarity.

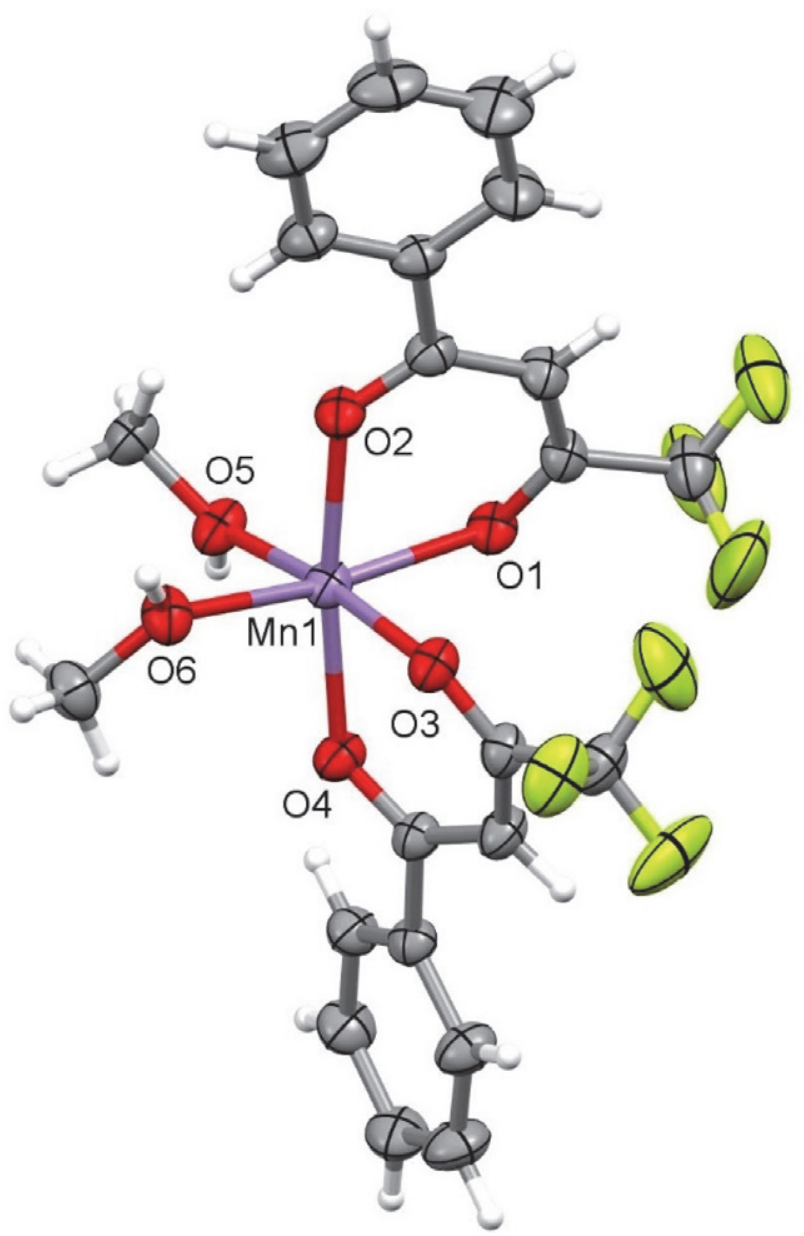

Figure 9. Structure of 4 . Disorder on both $\mathrm{CF}_{3}$ groups has been omitted for clarity. Displacement ellipsoids are drawn at 30\% probability level. a)

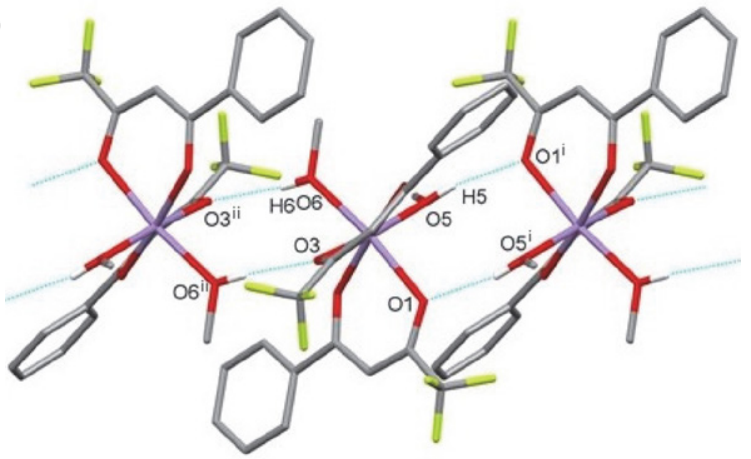

b)

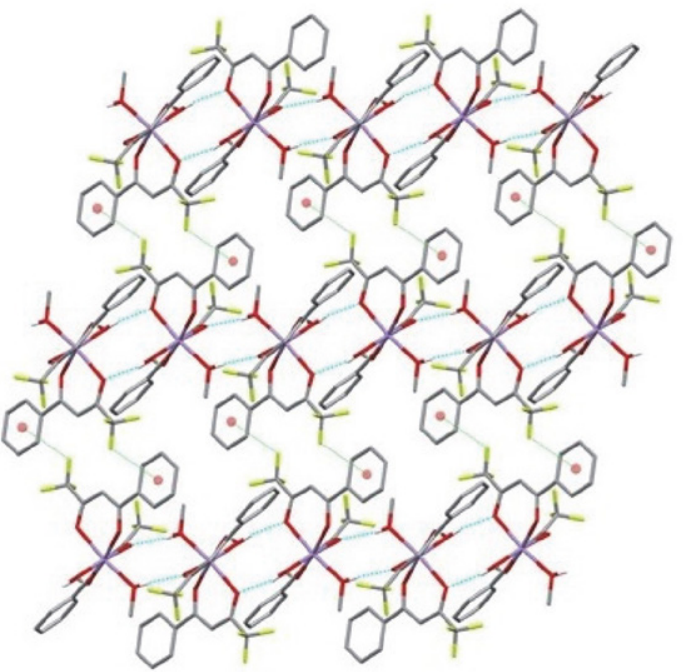

Figure 10. a) Hydrogen-bonded chain along $b$ axis in $\mathbf{4}$ formed by centrosymmetric $\mathrm{O} 5-\mathrm{H} 5 \cdots \mathrm{O} 1^{\mathrm{i}}$ and $\mathrm{O} 6-\mathrm{H} 6 \cdots 3^{\mathrm{ii}}$ interactions; b) chains are linked into a layer through $\mathrm{C}-\mathrm{F} \cdots \pi$ interactions. Blue and green dashed lines indicate hydrogen bonds and C-F $\cdots \pi$ interactions, respectively. For the sake of clarity, $\mathrm{H}$ atoms not involved in the motif shown have been omitted. For symmetry codes see Table 3. 
clined by $25.94(8)$ and $23.51(8)^{\circ}$. Each methanol ligand is involved in a centrosymmetric hydrogen-bonded motif via $\mathrm{O} 5-\mathrm{H} 5 \cdots{ }^{\mathrm{i}}{ }^{\mathrm{i}}$ and $\mathrm{O} 6-\mathrm{H} 6 \cdots \mathrm{O} 3^{\mathrm{ii}}$ interactions with the carbonyl oxygen atom at the trifluoromethyl substituent of the adjacent complex. Both centrosymmetric hydrogen bonds have the graph-set motif $\mathrm{R}_{2}^{2}(8)$ (Fig. 10 and Table 3) and enable the formation of a hydrogen-bonded chain along the $b$ axis. A centrosymmetric $\mathrm{C} 1-\mathrm{F} 3 \cdots \pi$ interaction between $\mathrm{CF}_{3}$ group and the benzene ring of tfpb ligand of the adjacent molecule is present with $d(\mathrm{~F} 3 \cdots C g 3)=3.661(4) \AA$ and $<(\mathrm{C} 1-\mathrm{F} 3 \cdots \mathrm{Cg} 3)=121.9(3)^{\circ}$, where $\mathrm{Cg} 3$ is $\mathrm{C} 5-\mathrm{C} 10$ ring centroid, connecting chains into a layer along the $b c$ plane (Fig. 10). There are no significant $\pi \cdots \pi$ interactions.

Table 6. Selected bond distances and angles for 4 .

\begin{tabular}{llll}
\hline Distance & $(\AA)$ & & \\
\hline Mn1-O1 & $2.1821(18)$ & Mn1-O2 & $2.1266(18)$ \\
Mn1-O3 & $2.1751(17)$ & Mn1-O4 & $2.1315(18)$ \\
Mn1-O5 & $2.1714(18)$ & Mn1-O6 & $2.173(2)$ \\
\hline Angle & $\left(^{\circ}\right)$ & & \\
\hline O1-Mn1-O2 & $82.45(7)$ & O1-Mn1-O3 & $89.13(7)$ \\
O1-Mn1-O4 & $91.80(7)$ & O1-Mn1-O5 & $92.79(7)$ \\
O1-Mn1-O6 & $171.30(7)$ & O2-Mn1-O3 & $92.40(7)$ \\
O2-Mn1-O4 & $172.98(7)$ & O2-Mn1-O5 & $94.84(8)$ \\
O2-Mn1-O6 & $88.87(7)$ & O3-Mn1-O4 & $83.46(7)$ \\
O3-Mn1-O5 & $172.69(7)$ & O3-Mn1-O6 & $90.62(7)$ \\
O4-Mn1-O5 & $89.43(7)$ & O4-Mn1-O6 & $96.81(8)$ \\
O5-Mn1-O6 & $88.54(8)$ & & \\
\hline
\end{tabular}

\section{Conclusion}

We have prepared and structurally characterized four manganese(II) bis(4,4,4-trifluoro-1-phenylbutane1,3-dionate) complexes with pyon, hpyon, pyF and methanol ligands. In all prepared compounds the coordination of the metal center is octahedral. Complexes 1-3 possess trans arrangement of ligands while in complex 4 the arrangement is cis. In 1-3 the $\mathrm{Mn}(\mathrm{tfpb})_{2}$ fragments deviate from planarity, the angles between the mean planes formed by the equatorial $\mathrm{MnO}_{4}$ cores and that of the tfpb chelate $\mathrm{C}_{3} \mathrm{O}_{2}$ moieties being in the range $14.48(6)-18.00(7)^{\circ}$. In 1 and 2 the axial positions are occupied by two pyon and hpyon ligands, respectively, bonded to the metal center through the $\mathrm{O}$ atom. Pyon and hpyon ligands are inclined toward the tfpb moiety by $78.60(5)^{\circ}$ (molecule A in 1 ), $44.51(5)^{\circ}$ (molecule B in $\mathbf{1}$ ) and $43.25(6)^{\circ}(2)$ representing a substantial deviation from $90^{\circ}$. Extended hydrogen bonding is present in $\mathbf{1}$ and $\mathbf{2}$ facilitating the formation of a three-dimensional supramolecular structure in $\mathbf{1}$ and a layered structure in $\mathbf{2}$ through $\mathrm{N}-\mathrm{H}$... O hydrogen bonding enhanced by $\mathrm{C}-\mathrm{H} \cdots \mathrm{O}$ interactions as well as $\mathrm{C}-\mathrm{F} \cdots \pi$ interactions. In 3 pyF ligand plays the main role in the formation of crystal aggregation due to the absence of the competing strong hydrogen bond donors. A layered structure is formed through $\mathrm{C}-\mathrm{H} \cdots \mathrm{O}$ and $\mathrm{C}-\mathrm{H} \cdots \mathrm{F}$ interactions as well as $\pi \cdots \pi$ and $\mathrm{C}-\mathrm{F} \cdots \pi$ interactions. In 4 a layered structure is formed through a combination of $\mathrm{O}-\mathrm{H} \ldots \mathrm{O}$ and $\mathrm{C}-\mathrm{F} \cdots \pi$ interactions.

\section{Supplementary Material}

CCDC 2024368-2024371 (1-4) contain the supplementary crystallographic data for this paper. These data can be obtained free of charge from The Cambridge Crystallographic Data Centre via www.ccdc.cam.ac.uk/data request/cif.

\section{Acknowledgment}

Financial support from the Slovenian Research Agency through the grant P1-0230-0175 is gratefully acknowledged. We thank EN-FIST Centre of Excellence, Dunajska cesta 156, 1000 Ljubljana, Slovenia for using the Supernova diffractometer.

\section{References}

1. C. B. Aakeröy, N. R. Champness, C. Janiak, CrystEngComm 2010, 12, 22-43. DOI:10.1039/B919819A

2. M. G. Goesten, F. Kapteijn, J. Gascon, CrystEngComm 2013, 15, 9249-9257. DOI:10.1039/c3ce41241e

3. (a) J. Liu, L. Chen, H. Cui, J. Zhang, L. Zhang, C.-Y. Su, Chem. Soc. Rev. 2014, 43, 6011-6061; DOI:10.1039/C4CS00094C

(b) A. Dhakshinamoorthy, H. Garcia, Chem. Soc. Rev. 2014, 43, 5750-5765; DOI:10.1039/C3CS60442J

(c) A. Herbst, C. Janiak, CrystEngComm 2017, 19, 4092-4117; DOI:10.1039/C6CE01782G

(d) M. D. Allendorf, V. Stavila, CrystEngComm 2014, 17, 229-246; DOI:10.1039/C4CE01693A

(e) T. Stolar, K. Užarević, CrystEngComm 2020, 22, 45114525; DOI:10.1039/D0CE00091D

(f) A. Dhakshinamoorthy, A. M. Asiri, H. García, Angew. Chem. Int. Ed. 2016, 55, 5414-5445;

DOI:10.1002/anie.201505581

(g) Z. Ajoyan, P. Marino, A. J. Howarth, CrystEngComm 2018, 20, 5899-5912; DOI:10.1039/C8CE01002A

(h) H. Li, K. Wang, Y. Sun, C. T. Lollar, J. Li, H.-C. Zhou, Mater. Today 2018, 21, 108-121;

DOI:10.1016/j.mattod.2017.07.006

(i) A. J. Howarth, Y. Liu, J. T. Hupp, O. K. Farha, CrystEngComm 2015, 17, 7245-7253; DOI:10.1039/C5CE01428J

(j) P. A. Kobielska, A. J. Howarth, O. K. Farha, S. Nayak, Coord. Chem. Rev. 2018, 358, 92-107;

DOI:10.1016/j.ccr.2017.12.010

(k) M. M. Sadiq, K. Suzuki, M. R. Hill, Chem. Commun., 2018, 54, 2825-2837. DOI:10.1039/C8CC00331A

4. (a) T. Koleša-Dobravc, A. Meden, F. Perdih, Acta Chim. Slov. 2015, 62, 261-271; DOI:10.17344/acsi.2014.1041 
(b) F. Perdih, Acta Crystallogr. 2012, C68, m64-m68; DOI:10.1107/S0108270112004386

(c) F. Perdih, J. Coord. Chem. 2012, 65, 1580-1591;

DOI:10.1080/00958972.2012.676168

(d) F. Perdih, Struct. Chem. 2014, 25, 809-819;

DOI:10.1007/s11224-013-0344-8

(e) F. Perdih, Monatshefte Chem. 2012, 143, 1011-1017;

DOI:10.1007/s00706-012-0760-2

(f) T. Koleša-Dobravc, A. Meden, F. Perdih, New J. Chem. 2015, 39, 4265-4277; DOI:10.1039/C5NJ00164A

(g) T. Koleša-Dobravc, A. Meden, F. Perdih, Monatshefte Chem. 2014, 145, 1263-1275;

DOI:10.1007/s00706-014-1215-8

(h) L. Bejaoui, J. Rohlíček, V. Eigner, A. Ismail, M. E. Bour, R. B. Hassen, Acta Chim. Slov. 2019, 66, 603-613;

DOI:10.17344/acsi.2019.5002

(i) R. Vafazadeh, Z. Mansouri, A. C. Willis, Acta Chim. Slov. 2020, 67, 516-521; DOI:10.17344/acsi.2019.5539

(j) R. Vafazadeh, A. Kazemi-nasab, A. C. Willis, Acta Chim. Slov. 2019, 66, 1010-1018. DOI:10.17344/acsi.2019.5333

5. (a) E. W. Berg, J. T. Truemper, J. Phys. Chem. 1960, 64, 487490; DOI:10.1021/j100833a029

(b) G. S. Shephard, D. A. Thornton, J. Mol. Struct. 1976, 34, 83-91; DOI:10.1016/0022-2860(76)80082-8

(c) M. A. Al-Anber, H. Daoud, Orient. J. Chem. 2013, 29, 905-909. DOI:10.13005/ojc/290307

6. Z. Otwinowski, W. Minor, Methods Enzymol. 1997, 276, 307326. DOI:10.1016/S0076-6879(97)76066-X

7. Rigaku Oxford Diffraction, CrysAlis PRO, Rigaku Corporation, Tokyo, Japan, 2015.

8. G. M. Sheldrick, Acta Crystallogr. 2015, C71, 3-8.

9. A. Altomare, M. C. Burla, M. Camalli, G. L. Cascarano, C. Giacovazzo, A. Guagliardi, A. G. G. Moliterni, G. Polidori, R. Spagna, J. Appl. Crystallogr. 1999, 32, 115-119.

DOI:10.1107/S0021889898007717

10. (a) M. H. Dickman, Acta Crystallogr. 1999, C55, IUC9900146. DOI:10.1107/S0108270199098558

(b) D. A. Souza, A. S. Florencio, J. W. de M. Carneiro, S. S. Soriano, C. B. Pinheiro, M. A. Novak, M. G. F. Vaz, Inorg. Chim. Acta 2008, 361, 4024-4030;

DOI:10.1016/j.ica.2008.03.043

(c) C. Benelli, A. Caneschi, D. Gatteschi, M. C. Melandri, P. Rey, Inorg. Chim. Acta 1990, 172, 137-139.

DOI:10.1016/S0020-1693(00)80847-6

11. J. Bernstein, R. E. Davis, L. Shimoni, N.-L. Chang, Angew. Chem. Int. Ed. Engl. 1995, 34, 1555-1573.

DOI:10.1002/anie.199515551

12. A. Tyl, M. Nowak, J. Kusz, Acta Crystallogr. 2008, C64, o661o664. DOI:10.1107/S0108270108033660

13. V. M. Deflon, K. E. Bessler, M. Kretschmar, U. Abram, Z. Anorg. Allg. Chem. 2000, 626, 1545-1549.

14. C. R. Groom, I. J. Bruno, M. P. Lightfoot, S. C. Ward, Acta Crystallogr. 2016, B72, 171-179.

DOI:10.1107/S2052520616003954

15. See, for example: (a) K. D. Hughey, N. C. Harms, K. R. O’Neal, A. J. Clune, J. C. Monroe, A. L. Blockmon, C. P. Landee, Z. Liu,
M. Ozerov, J. L. Musfeldt, Inorg. Chem. 2020, 59, 2127-2135; DOI:10.1021/acs.inorgchem.9b02394

(b) R. B. P. Pesci, E. J. de Souza, E. Niquet, O. R. Nascimento, R. B. Viana, V. M. Deflon, J. Mol. Struct. 2019, 1194, 104-111; DOI:10.1016/j.molstruc.2019.05.041

(c) F. A. Mautner, C. Berger, C. Gspan, B. Sudy, R. C. Fischer, S. S. Massoud, Polyhedron 2017, 130, 136-144;

DOI:10.1016/j.poly.2017.04.012

(d) L.-F. Wang, J.-Z. Qiu, Y.-C. Chen, J.-L. Liu, Q.-W. Li, J.-H. Jia, M.-L. Tong, Inorg. Chem. Front. 2017, 4, 1311-1318; DOI:10.1039/C7QI00221A

(e) B. Zhou, D. Yan, Angew. Chem. Int. Ed. 2019, 58, 1512815135. DOI:10.1002/anie.201909760

16. See, for example: (a) T. R. Hayes, P. A. Lyon, C. L. Barnes, S. Trabue, P. D. Benny, Inorg. Chem. 2015, 54, 1528-1534; DOI:10.1021/ic502520x

(b) D. Septiadi, A. Aliprandi, M. Mauro, L. D. Cola, RSC Adv. 2014, 4, 25709-25718. DOI:10.1039/C4RA02351J

17. (a) N. Uzun, A. T. Çolak, F. M. Emen, G. Kismali, O. Meral, M. Alpay, G. K. Çılgı, E. Şahin, J. Coord. Chem. 2015, 68, 949-967; DOI:10.1080/00958972.2014.1003371

(b) H. M. Kieler, M. J. Bierman, I. A. Guzei, P. J. Liska, R. W. McGaff, Chem. Commun. 2006, 3326-3328.

DOI:10.1039/B606537F

18. (a) R. G. Pearson, J. Am. Chem. Soc. 1963, 85, 3533-3539; DOI:10.1021/ja00905a001

(b) R. G. Parr, R. G. Pearson, J. Am. Chem. Soc. 1983, 105, 7512-7516. DOI:10.1021/ja00364a005

19. (a) K. Kumar, S. Chorazy, K. Nakabayashi, H. Sato, B. Sieklucka, S. Ohkoshi, J. Mater. Chem. C 2018, 6, 8372-8384; DOI:10.1039/C8TC01305E

(b) K. Kumar, D. Abe, K. Komori-Orisaku, O. Stefańczyk, K. Nakabayashi, J. R. Shakirova, S. P. Tunik, S. Ohkoshi, RSC Adv. 2019, 9, 23444-23449; DOI:10.1039/C9RA03276B

(c) S. Chorazy, J. Wang, S. Ohkoshi, Chem. Commun. 2016, 52, 10795-10798. DOI:10.1039/C6CC05337H

20. F. Perdih, Acta Crystallogr. 2017, C73, 960-967.

21. S. Petriček, Polyhedron 2019, 167, 11-25.

DOI:10.1016/j.poly.2019.03.050

22. A. A. Dar, S. Sen, S. K. Gupta, G. N. Patwari, R. Murugavel, Inorg. Chem. 2015, 54, 9458-9469.

DOI:10.1021/acs.inorgchem.5b01308

23. J. M. Rawson, R. E. P. Winpenny, Coord. Chem. Rev. 1995, 139, 313-374. DOI:10.1016/0010-8545(94)01117-T

24. S. Petriček, Molecules, 2020, 25, 846. DOI:10.3390/molecules25040846

25. (a) T. Koleša-Dobravc, K. Maejima, Y. Yoshikawa, A. Meden, H. Yasui, F. Perdih, New J Chem 2017, 41, 735-746; DOI:10.1039/C6NJ02961B

(b) T. Koleša-Dobravc, K. Maejima, Y. Yoshikawa, A. Meden, H. Yasui, F. Perdih, New J. Chem. 2018, 42, 3619-3632. DOI:10.1039/C7NJ04189F 


\section{Povzetek}

Sintetizirali smo manganove(II) bis(4,4,4-trifluoro-1-fenilbutan-1,3-dionato) komplekse s piridin-4-onom (pyon), 3-hidroksipiridin-2-onom (hpyon), 1-fluoropiridinom (pyF) in metanolom ter določili strukture z monokristalno rentgensko difrakcijo. V vseh kompleksih je koordinacija kovinskega centra oktaedrična. Pri spojinah $\left[\mathrm{Mn}(\operatorname{tfpb})_{2}(\mathrm{pyon})_{2}\right](\mathbf{1})$ in $\left[\mathrm{Mn}(\mathrm{tfpb})_{2}(\mathrm{hpyon})_{2}\right]$ (2) so prisotne številne vodikove vezi, ki omogočajo tvorbo tridimenzionalne supramolekularne strukture v 1 in plastovite strukture v 2 z N-H $\cdots$ O vodikovimi vezmi ojačane z C-H $\cdots$ O interakcijami ter tudi C-F $\cdots \pi$ interakcije. Pri $\left[\mathrm{Mn}(\mathrm{tfpb})_{2}(\mathrm{pyF})_{2}\right](3)$ je prisotna plastovita struktura $\mathrm{z} \mathrm{C}-\mathrm{H} \cdots \mathrm{O}$ in $\mathrm{C}-\mathrm{H} \cdots \mathrm{F}$ interakcijami ter tudi $\mathrm{z} \pi \cdots \pi$ in C-F $\cdots \pi$ interakcijami. Pri $\left[\mathrm{Mn}(\mathrm{tfpb})_{2}(\mathrm{MeOH})_{2}\right](4)$ je prisotna plastovita struktura s kombinacijo $\mathrm{O}-\mathrm{H} \cdots \mathrm{O}$ in $\mathrm{C}-\mathrm{F} \cdots \pi$ interakcij. 